\title{
STRATEGI MANAJEMEN RISIKO USAHATANI MELON DI LAHAN PASIR PANTAI KABUPATEN KULON PROGO
}

\author{
Ananti Yekti ${ }^{1}$, Dwidjono Hadi Darwanto ${ }^{2}$, Jamhari, Slamet Hartono ${ }^{2}$ \\ ${ }^{1}$ Politeknik Pembangunan Pertanian Yogyakarta-Magelang \\ J1. Kusumanegara No.2, Yogyakarta, 55167 \\ Email : anantiyekti@yahoo.com \\ ${ }^{2}$ Fakultas Pertanian Universitas Gadjah Mada \\ J1. Flora, Bulaksumur, Catur Tunggal, Sleman, D.I. Yogyakarta. 55281
}

\begin{abstract}
Farmer play a role as a worker as well as a manager in his farm. As a manager, farmer has the function to managing risks and formulating strategies to minimize the risk impact. Objectives of this study were to: 1) know the perception of coastal sand farmers about farming risk 2) identify and analyze the risk management strategy that melon farmers have implemented; 3) formulate activity recommendation to reduce the impact of melon farm risk in coastal sand. The study was conducted in April - May 2014, with locations in District of Galur. Data used in the study were taken from 50 respondents, analyzed descriptively referring to the model Jolly (1993) and Matlon (1991). The results showed that intercropping cultivation system, land rotation and crop rotation were ex-ante management strategies that farmers should take. An interactive risk management strategy that needs to be addressed is: selection of planting season, inorganic fertilization application and pesticide as well as the need to encourage "labor gathering" culture. Seeking crops with lower production risks becomes an alternative risk management expost in order to suppress further losses. Accessibility of farmers to formal financial institutions is known to be good.
\end{abstract}

Keywords: Melon Farming, Risk Management Strategy, Coastal Sand Area

\section{PENDAHULUAN}

Proses produksi merupakan sumber utama dari pendapatan untuk produsen pertanian, maka menjadi hal penting bagi petani untuk mengenali dan mengelola risiko produksi (Ullah et al., 2015). Produsen dalam konteks ini adalah petani, menyadari bahwa risiko merupakan bagian dari lingkungan bisnis yang harus dikelola. Bagi individu petani manajemen risiko merupakan suatu upaya untuk menemukan kombinasi yang sesuai dari aktifitas dengan hasil yang tidak pasti dan expected return yang bervariasi (Aimin, 2010). Fakta bahwa petani hidup dalam kondisi iklim dan kelembagaan yang berbeda memberikan implikasi adanya perbedaan persepsi risiko. Keadaan ini disebakan karena: 1) probabilitas yang berbeda dari faktor risiko tertentu 2) mentalitas dan kesadaran petani yang berbeda dan atau 3) campuran keduanya (Borges \& Machado, 2012). Pemahaman akan persepsi risiko yang tepat dapat dilihat sebagai prasyarat untuk memilih strategi manajemen risiko yang efisien, karena petani yang tidak sadar akan risiko yang dihadapi tidak akan mampu mengelola secara efektif (Sulewski \& Gajewska, 2014).

Alih fungsi lahan pertanian merupakan fenomena yang sulit untuk dibendung saat ini. Salah satu alternatif yang dapat dilakukan untuk mengatasi masalah alih fungsi lahan pertanian adalah dengan pemanfaatan lahan marjinal menjadi lahan pertanian. Jenis lahan marjinal berpotensi tinggi untuk dimanfaatkan di Indonesia adalah lahan 
pantai, karena Indonesia merupakan negara kepulauan memiliki panjang garis pantai mencapai $106.000 \mathrm{~km}$ dengan potensi luas lahan 1.060.000 Ha. Kulon Progo merupakan salah satu kabupaten yang berada di provinsi DIY berbatasan langsung dengan samudra hindia yang telah mengelola lahan pasir di pantai sebagai lahan pertanian mulai akhir tahun 1990an. Setelah berbagai proyek pengembangan pertanian kawasan pantai masuk, secara signifikan lahan dipesisir pantai tersebut mampu ditingkatkan produktivitasnya dan berbagai komoditas pertanian mulai diusahakan. Martono (2007) menyebutkan bahwa kawasan pesisir Kabupaten Kulon Progo mempunyai karakteristik yang unik, yaitu; (1) bentuk lahan (landform) pesisirnya relatif landai, (2) sebagian besar penduduk yang bermukim di kawasan pesisir Kulon Progo adalah petani dan sedikit sekali yang berprofesi sebagai nelayan, (3) sebagian kecil lahan kawasan pesisir telah dimanfaatkan untuk pertanian dengan komoditas; cabai merah, melon dan semangka dan mampu menghasilkan panen bagus, (4) air tanah relatif dangkal dengan kualitas baik berasa tawar dan belum terjadi intrusi air laut, (5) terdapat lahan-lahan tidur cukup luas yang belum termanfaatkan. Upaya perbaikan sifat tanah dan lingkungan mikro telah dilakukan oleh petani, antara lain dengan melakukan penyiraman yang teratur, penggunaan mulsa penutup tanah, penggunaan pemecah angin, penggunaan bahan pembenah tanah, penggunaan lapisan kedap, dan pemberian pupuk (baik organik maupun anorganik). Berbagai keterbatasan sifat fisik dan agroklimat menyebabkan usahatani di lahan pantai cenderung memiliki risiko lebih besar. Salah satu sentra penghasil melon lahan pasir di Kabupaten Kulon Progo adalah di Kecamatan Galur.

Komoditas hortikultura yang relatif banyak dibudidayakan di wilayah pasir pantai kabupaten Kulon Progo adalah melon. Meskipun melon memiliki potensi nilai ekonomi yang tinggi namun sesungguhnya usahatani melon juga memiliki potensi risiko usahatani yang tinggi pula. Kebutuhan sarana produksi yang mahal, sifat tanaman melon yang hanya dapat dipanen satu kali, serta sifat rentan terhadap perubahan iklim, serangan hama dan penyakit serta fluktuasi harga melon di pasar menjadikan budidaya melon memiliki risiko usahatani relatif lebih tinggi dibanding komoditas hortikultura. Terlepas dari besarnya risiko yang harus dihadapi, potensi pendapatan atau keuntungan komoditas melon menjadi daya tarik dan motivasi bagi petani untuk membudidayakannya, baik pada lahan yang subur sampai dengan pada lahan marjinal.

Saptana et al., (2010) menyebutkan tujuan manajemen risiko usahatani adalah untuk mencegah petani dari kegagalan, mengurangi pengeluaran dan biaya produksi, meningkatkan keuangan serta mengurangi kerugian yang mungkin timbul. Memahami strategi manajemen risiko dapat menjadi titik penting untuk menyusun formulasi kebijakan yang efektif dan pengembangan teknologi (Matlon, 1991). Petani dalam usahataninya berperan sebagai pekerja sekaligus sebagai manajer bagi usahataninya. Sebagai seorang manajer maka petani harus mampu membuat keputusan yang tepat terkait dengan usahataninya (Suratiyah, 2014). Keputusan yang diambil oleh petani melon 
meliputi pemilihan teknologi budidaya, penentuan lokasitanam, sistem penjualan hasil panen maupun cara memperoleh modal. Dari uraian permasalahan, latar belakang dan kondisi situasi seperti yang telah dijelaskan sebelumnya, dapat disusun tujuan dari penelitian ini, yaitu: (1) mengetahui persepsi petani melon lahan pasir tentang risiko usahatani (2) mengidentifikasi dan menganalisis strategi manajemen risiko petani melon di lahan pasir pantai dalam menghadapi risiko usahatani (3) merumuskan saran rekomendasi kegiatan untuk mengurangi dampak risiko.

\section{METODE PENELITIAN}

Penelitian dilakukan pada bulan Maret - April 2014. Wilayah penelitian ditentukan secara purposive yaitu wilayah yang memiliki lahan pasir dan berbatasan langsung dengan laut. Kecamatan Galur dipilih mewakili sentra produksi melon pada zona bagian selatan Kabupaten Kulon Progo. Pemilihan Desa dilakukan secara purposive, yaitu Desa Karang Sewu yang merupakan desa berbatasan langsung dengan samudera Indonesia. Penentuan sample dilakukan secara quota sampling. Jumlah sampel yang diambil sebanyak 50 petani. Pengambilan data dilakukan dengan teknik wawancara menggunakan kuisioner. Informasi yang diambil berkaitan dengan persepsi petani di lahan pasir pantai terhadap risiko, persepsi petani terhadap faktor-faktor yang mempengaruhi risiko usahatani melon, strategi petani dalam mengelola risiko usahatani melon di lahan pasir serta informasi lain yang terkait dengan kajian ini. Untuk mendapatkan pilihan strategi pengelolaan usahatani melon merujuk model dari Jolly (1983) dan Matlon (1991) yang diaplikasikan oleh Adiyoga dan Soetiarso (1999) serta Saptana et al., (2010). Strategi manajemen risiko usahatani dikelompokkan menjadi: (a) strategi manajemen risiko ex-ante terutama ditujukan untuk antisipatif terjadinya goncangan, (b) strategi manajemen risiko interaktice yang ditujukan untuk responsif pada saat terjadinya goncangan, (c) strategi manajemen risiko ex-post ditujukan untuk adaptif setelah terjadi goncangan. Analisis data dilakukan secara deskriptif kualitatif menggunakan tabel frekuensi.

\section{HASIL DAN PEMBAHASAN}

Persepsi Petani Melon Lahan Pasir Terhadap Risiko Usahatani

MenurutKamus Besar Bahasa Indonesia (1995) persepsi adalah : (1) tanggapan (penerimaan) langsung dari sesuatu, serapan dan (2) proses seseorang mengetahui beberapa hal melalui pancainderanya. Meski demikian apa yang dipersepsikan seseorang dapat berbeda dari kenyataan yang obyektif (Robbins, 1998). Sejumlah faktor yang mempengaruhi persepsi menurut Robbins adalah pelaku persepsi, obyek atau target yang dipersepsikan dan situasi. Berdasar Tabel 1 diketahui bahwa sebagian besar petani (36\%) menganggap risiko adalah semua hal yang cenderung menjurus kepada terjadinya kerugian usahatani melon. Dalam konteks ini petani telah memandang risiko usahatani dengan memasukan risiko produksi maupun risiko harga produk seperti yang dinyatakan oleh Saptana et al, (2010) bukan sekedar penyimpangan atau deviasi dari hasil yang diharapkan (Adiyoga dan Soetiarso, 1999). Sebesar 50\% petani lahan pasir berpersepsi 
bahwa usahatani melon dikatakan gagal apabila produksi rendah dan harga jual jatuh.

Pernyataan ini mengacu pada pengalaman

petani yang pernah mengalami gagal panen karena serangan hama penyakit maupun banjir, mengalami rendahnya harga jual akibat panen raya diberbagai sentra produksi melon lainnya.

Tabel 1. Persepsi Petani Melon Di Lahan Pasir Pantai terhadap Risiko Usahatani

\begin{tabular}{|c|c|c|c|}
\hline No. & Persepi Petani & Frekuensi & Persentase $(\%)$ \\
\hline \multirow[t]{6}{*}{1.} & Risiko menurut persepsi petani: & & \\
\hline & $\begin{array}{l}\text { a. Semua hal yang menyebabkan terjadinya penyimpangan produksi } \\
\text { melon yang diharapkan }\end{array}$ & 12 & 24 \\
\hline & $\begin{array}{l}\text { b. Semua hal yang cenderung menjurus kepada terjadinya kerugian } \\
\text { usahatani melon }\end{array}$ & 18 & 36 \\
\hline & $\begin{array}{l}\text { c. Semua hal yang dapat membahayakan usahatani melon, tetapi dapat } \\
\text { dicegah atau dikurangi dampaknya jika diwaspadai sejak awal }\end{array}$ & 15 & 30 \\
\hline & $\begin{array}{l}\text { d. Konsekuensi yang membebani petani jika hendak berusahatani melon, } \\
\text { misalnya : menyediakan modal, saprodi, dll }\end{array}$ & 5 & 10 \\
\hline & Total & 50 & 100 \\
\hline \multirow[t]{5}{*}{2.} & Usahatani melon dikatagorikan gagal menurut petani: & & \\
\hline & $\begin{array}{l}\text { a. Produksi melon yang dihasilkan relatif rendah }(<50 \% \text { dari produksi } \\
\text { biasanya) }\end{array}$ & 14 & 28 \\
\hline & b. Harga jual melon yang diterima rendah (tidak seperti yang diharapkan) & 11 & 22 \\
\hline & c. Produksi dan harga melon keduanya relatif rendah & 25 & 50 \\
\hline & Total & 50 & 100 \\
\hline \multirow[t]{5}{*}{3.} & Tingkat risiko produksi usahatani melon menurut persepsi petani: & & \\
\hline & a. Tinggi ( $>50 \%$ gagal panen) & 39 & 78 \\
\hline & b. Sedang ( $25 \%-50 \%$ gagal panen $)$ & 8 & 16 \\
\hline & c. Rendah (<50\% gagal panen $)$ & 3 & 6 \\
\hline & Total & 50 & 100 \\
\hline \multirow[t]{5}{*}{4.} & Tingkat risiko harga melon menurut persepsi petani: & & \\
\hline & a. Tinggi (harga jatuh $>50 \%$ dari harga tertinggi saat itu) & 34 & 64 \\
\hline & b. Sedang (harga jatuh $25 \%-50 \%$ dari harga tertinggi saat itu) & 12 & 24 \\
\hline & c. Rendah ( $<25 \%$ dari harga tertinggi saat itu) & 4 & 8 \\
\hline & Total & 50 & 100 \\
\hline \multirow[t]{5}{*}{5.} & Tingkat keuntungan usahatani: & & \\
\hline & a. Tinggi (rasio penerimaan terhadap biaya $\geq 2$ ) & 40 & 80 \\
\hline & b. Sedang (rasio penerimaan terhadap biaya $1,5-\leq 2$ ) & 8 & 16 \\
\hline & c. Rendah (rasio penerimaan terhadap biaya < 1,5 ) & 2 & 4 \\
\hline & Total & 50 & 100 \\
\hline
\end{tabular}

Katagori risiko produksi melon panen. Perbedaan harga dapat terjadi karena menurut persepsi petani adalah tinggi (78\%), perbedaan kualitas hasil panen, penentuan didorong oleh fakta karateristik tanaman waktu tanam dan stok melon di pasaran. melon yang hanya berbuah dan dipanen satu kali dalam satu musim tanam, rentan terhadap serangan hama penyakit serta rentan terhadap kelebihan air. Tingkat risiko harga melon dikatagorikan tinggi oleh $64 \%$ petani. Harga jual melon yang diharapkan seringkali berbeda dengan harga yang terjadi pada saat Petani menilai keuntungan yang diperoleh tanpa memperhitungkan upah tenaga kerja dalam keluarga. Keuntungan usahatani melon termasuk katagori tinggi menurut persepsi $80 \%$ petani. Ini terlihat dari keputusan petani yang selalu memasukan melon sebagai unsur penyusun pola tanam setiap tahunnya. 
Persepsi Petani Melon Mengenai Faktor-

Faktor yang Berpengaruh terhadap Risiko

\section{Usahatani}

Pengertian risiko usahatani dalam konteks ini adalah kemungkinan terjadinya kegagalan produksi atau kerugian pada usahatani melon. Petani melon mengkatagorikan faktor-faktor yang berpengaruh terhadap risiko usahatani dalam dua katagori. Menurut persepsi petani faktor mempengaruhi usahatani melon adalah faktor eksternal (perubahan iklim, serangan OPT dan harga jual). Faktor eksternal tersebut memberikan kontribusi tertinggi sebagai faktor penyebab risiko usahatani, sedangkan faktor internal (ketersediaan modal dan kemampuan manajerial) memberikan kontribusi relatif kecil menurut persepsi petani melon

Tabel 2. Faktor-Faktor Yang Mempengaruhi Risiko Usahatani Melon Menurut Persepsi Petani Lahan Pasir Pantai Di Kabupaten Kulon Progo

\begin{tabular}{|c|c|c|c|}
\hline No. & Faktor Yang Berpengaruh Terhadap Risiko Usahatani Melon & Frekuensi & Persentase $(\%)$ \\
\hline 1 & Perubahan iklim / cuaca & 33 & 66 \\
\hline 2 & Serangan OPT & 8 & 16 \\
\hline 3 & Harga jual melon jatuh & 1 & 2 \\
\hline 4 & Ketersediaan modal usaha & 3 & 6 \\
\hline 5 & Kemampuan manajerial & 5 & 10 \\
\hline & Total & 50 & 100 \\
\hline
\end{tabular}

Sebanyak $66 \%$ petani menempatkan perubahan cuaca/iklim sebagai faktor yang paling berpengaruh terhadap risiko usahatani. Ini sejalan dengan penelitian Saptana (2010) menempatkan perubahan iklim sebagai faktor yang paling berpengaruh terhadap risiko, namun berbeda dengan temuan Zuhriyah dan Happy (2013) yang menempatkan serangan OPT pada peringkat tertinggi. Faktor eksternal yang berada diluar kontrol petani tersebut sangat menentukan kualitas hasil panen yang selanjutnya akan mempengaruhi harga jual melon. Berat buah, bentuk buah, kesempurnaan nett (jaring), warna buah yang merata, kekerasan (mentes) buah serta tingkat kemanisan sangat menentukan harga jual melon.

Strategi Manajemen Risiko Usahatani Melon

Strategi Manajemen Risiko Ex-Ante

Tujuan utama strategi manajemen risiko yang dilakukan petani sebelum terjadinya risiko(strategimanajemen risiko ex-ante) pada dasarnya adalah dalam rangka memperkecil variabilitas yang terjadi, baik dari sisi hasil produksi maupun penerimaan usahatani. Beberapa aktivitas yang direncanakan sebelum melakukan aktivitas usahatani antara lain meliputi: penyusunan pola tanam, sistem produksi yang akan diterapkan, varietas yang akan dibudidayakan, dan lokasi dan lahan yang digunakan.

Merujuk Tabel 3 dapat diketahui bahwa petani lahan pasir memiliki pola tanam yang sangat beragam, yaitu sebanyak 26 macam. Tanaman hortikultura (sayuran \& buah) mendominasi sebagai unsur penyusun pola tanam dibanding tanaman pangan dan palawija. 
Tabel 3. Strategi Manajemen Risiko Ex-ante Petani Melon Di Lahan Pasir Pantai Kabupaten Kulon Progo

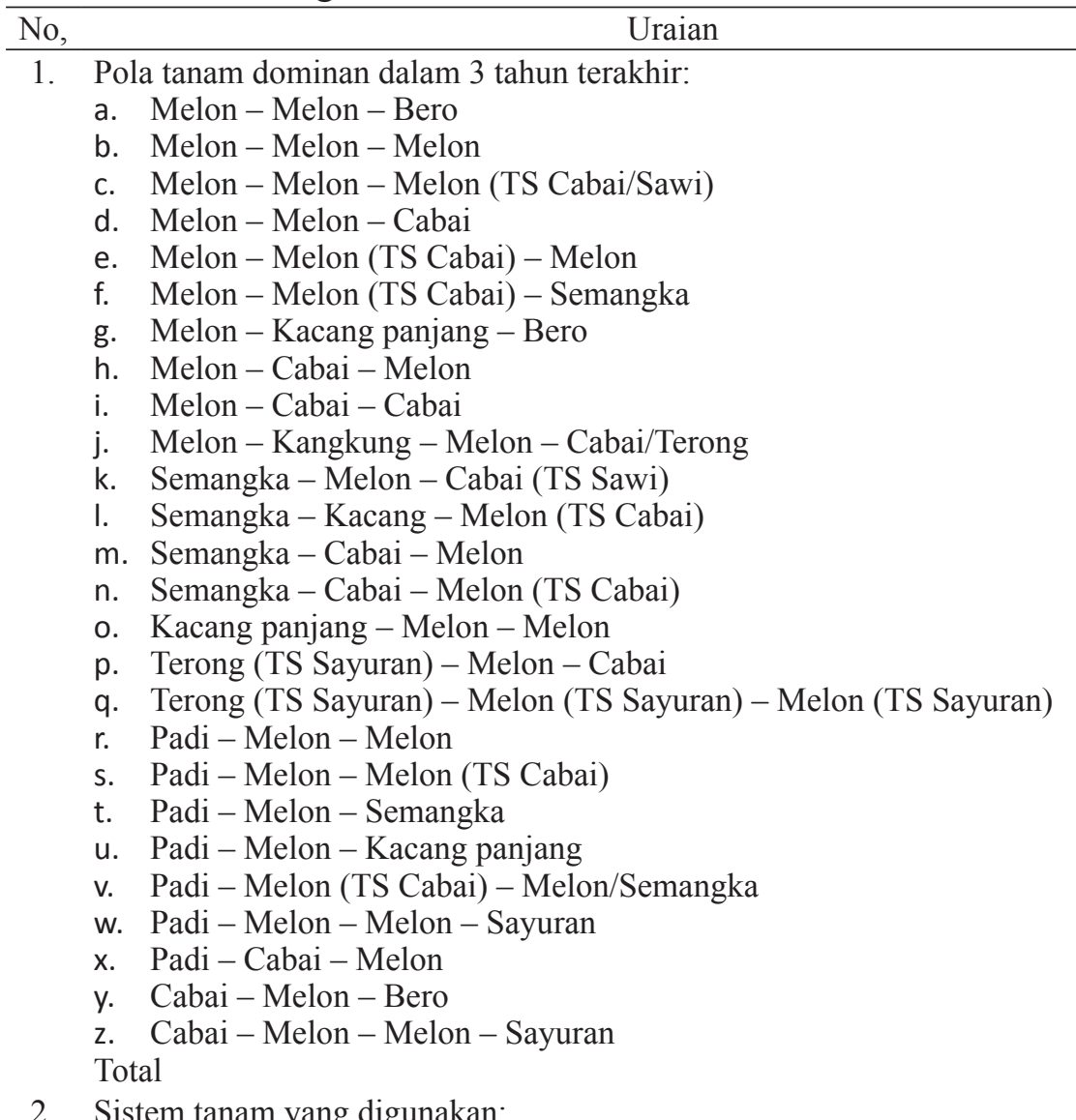

Frekuensi Persentase (\%)

2. Sistem tanam yang digunakan:
a. Monokultur
b. Tumpang sari/tumpang gilir
Total

3. Alasan mengikuti pola tanam secara konsisten memasukan melon dalam 3 tahun terakhir:
a. Dipandang paling menguntungkan
b. Sesuai dengan kondisi iklim setempat
c. Sesuai dengan kondisi agroekosistem
d. Jika berbeda bisa terjadi serangan OPT
Total

4. Teknik bududaya melon yang digunakan:
a. Telasar
b. Lanjaran
Total

5. Alasan menggunakan sistem budidaya telasar:
a. Secara keseluruhan lebih menguntungkan dibanding sistem lanjaran
b. Penggunaan modal produksi lebih sedikit
c. Mengurangi risiko kerugian jika terjadi kegagalan
e. Hemat tenaga kerja
Total
$\begin{array}{ccc}\text { a. Selalu varietas tunggal pada semua lahan yang diusahakan } & 50 & 100 \\ \text { Total } & 50 & 100\end{array}$

7. Banyaknya lokasi/persil pertanaman melon dalam setahun:
a. Hanya ditanam disatu lokasi dalam setahun
b. Lebih sari satu lokasi ditanam serentak dalam setahun
c. Dibeberapa lokasi sepanjang tahun (pindah-2 tempat) 
Strategi lainnya yang diterapkan untuk mengeliminir risiko khususnya risiko pendapatan adalah dengan memasukan sistem tumpang sari/tumpung gilir dalam pola tanam, berbeda dengan budidaya melon di lahan sawah yang ditanam secara monokultur. Ditemukan pula petani yang menanam melon lebih dari satu kali dalam satu tahun. Petani memasukan tanaman melon dalam pola tanam selama 3 tahun terakhir dengan pertimbangan sebagai pola tanam yang paling menguntungkan. Teknik budidaya yang diterapkan pada musim kemarau dan musim hujan adalah sistem telasar seluruhnya dengan alasan utama meminimalisir penggunaan modal produksi.

Sistem lanjaran dianggap petani tidak sesuai untuk diterapkan di lahan pasir pantai. Berbeda dengan hasil penelitian Yekti et al, 2014 tentang melon di lahan sawah mendapati budidaya melon sepenuhnya dilakukan secara monokultur, baik dengan sistem lanjaran maupun telasar dan ragam pola tanam hanya ada delapan macam

Seluruh petani (100\%) menyatakan hanya menggunakan satu varietas pada setiap pertanaman melon yang diusahakan. Alasan yang dikemukakan adalah varietas tersebut dapat menghasilkan buah yang keras "mentes", tidak mudah menjadi lunak sehingga lebih disukai oleh pedagang karena tingkat lebih lama. Petani mayoritas menanam hanya pada satu lokasi dalam satu tahun (94\%), didasari pertimbangan bahwa usahatani di lahan pasir memerlukan curahan tenaga kerja yang sangat intensif. Lokasi yang terpencar atau saling berjauhan menyebabkan petani sulit untuk melakukan pemeliharaan. Hanya 6\% petani melon menanam lebih dari satu lokasi dalam satu tahun. Petani yang membudidayakan melon lebih pada satu petak lahan (persil) cenderung akan membudidayakan pada lahan yang saling berdekatan, terutama apabila sumber tenaga kerja didominasi oleh tenaga kerja dalam keluarga.

\section{Manajemen Risiko Interactive}

Strategi manajemen risiko selama proses produksi berlangsung dinamakan strategi manajemen risiko interaktive. Risiko yang mungkin terjadi antara lain: gagal panen, penurunan produktivitas, penurunan kualitas produk. Pada awal musim tanam petani akan mempunyai harapan subyektif berdasar dari pengalaman usahatani sebelumnya. Sejalan dengan bertambahnya usia tanaman, maka petani akan menyesuaikan dan mengatur aktifitas budidaya, terkait terjadinya gangguan dari luar. Meskipun secara intutif petani mengetahui probabilitas keberhasilan pertanaman pada musim kemarau lebih baik dan berbagai literature budidaya melon juga menyatakan budidaya melon pada musim kemarau lebih mudah dilakukan dibanding musim hujan, namun mayoritas petani (62\%) memutuskan menanam melon pda musim kemarau dan juga musim penghujan. Motivasi meraih keuntungan lebih tinggi mendorong petani untuk menanam melon diluar musim.

Risiko pertama saat awal budidaya adalah matinya bibit pada saat umur belum mencapai dua minggu. Mayoritas petani (70\%) melakukan penyulaman sebelum tanaman berumur satu minggu. Hanya 2\% petani yang tidak melakukan penyulaman dikarenakan tidak ditemukan tanaman yang mati sampai umur 2 minggu. 
Tabel 4. Strategi Manajemen Risiko Interactive Petani Melon pada Agroekosistem Lahan Pasir Di Kabupaten Kulon Progo

\begin{tabular}{|c|c|c|c|}
\hline No. & Uraian & Frekuensi & Persen $(\%)$ \\
\hline \multirow[t]{5}{*}{1.} & Waktu penanaman melon: & & \\
\hline & a. Pada Musim Hujan saja & 1 & 2 \\
\hline & b. Pada Musim Kemarau saja & 18 & 36 \\
\hline & c. Pada Musim Hujan dan Kemarau & 31 & 62 \\
\hline & Total & 50 & 100 \\
\hline \multirow[t]{5}{*}{2.} & Tindakan bila sebagian tanaman di lapangan mati pada umur: & & \\
\hline & a. 1-7 HST: dilakukan penyulaman & 35 & 70 \\
\hline & b. 8-14 HST : dilakukan penyulaman & 14 & 28 \\
\hline & c. Tidak dilakukan penyulaman & 1 & 2 \\
\hline & Total & 50 & 100 \\
\hline \multirow[t]{5}{*}{3.} & Jarak tanam yang digunakan: & & \\
\hline & a. Jarak tanam rapat & 37 & 74 \\
\hline & b. Jarak tanam sedang & 11 & 22 \\
\hline & c. Jarak tanam renggang/lebar & 2 & 4 \\
\hline & Total & 50 & 100 \\
\hline \multirow[t]{6}{*}{4.} & Jenis pupuk yang digunakan pada pertanaman melon: & & \\
\hline & a. Puuk majemuk saja & 0 & 0 \\
\hline & b. Pupuk majemuk dan organik & 0 & 0 \\
\hline & c. Pupuk tunggal, majemuk dan pupuk organik & 50 & 100 \\
\hline & Total then & 50 & 100 \\
\hline & Penggunaan pupuk pada MK vs MH: & & \\
\hline \multirow[t]{4}{*}{5.} & a. Tidak berbeda jenis maupun volumenya & 13 & 42 \\
\hline & b. Tidak berbeda jenis, tetapi beda volumenya & 14 & 45 \\
\hline & c. Berbeda jenis dan volumenya & 4 & 13 \\
\hline & Total & 31 & 100 \\
\hline \multirow[t]{5}{*}{6.} & Penggunaan pestisida pada MK vs MH: & & \\
\hline & a. Tidak berbeda jenis maupun volumenya & 16 & 51 \\
\hline & b. Tidak berbeda jenis, tetapi beda volumenya & 12 & 39 \\
\hline & c. Berbeda jenis maupun volumenya & 3 & 10 \\
\hline & Total & 31 & 100 \\
\hline \multirow[t]{5}{*}{7.} & Metode pengendalian hama penyakit yang dilakukan: & & \\
\hline & a. Sebagai tindakan pencegahan (preventif) & 9 & 18 \\
\hline & b. Sebagai tindakan pembasmian (curative) & 10 & 20 \\
\hline & c. Sebagai tindakan preventif dan curative & 31 & 62 \\
\hline & Total & 50 & 100 \\
\hline \multirow[t]{5}{*}{8.} & Kecenderungan petani dalam mengendalikan OPT: & & \\
\hline & a. Hanya menggunakan pestisida kimia & 0 & 0 \\
\hline & b. Menggunakan pestisida nabati & 0 & 0 \\
\hline & c. Menggunakan pestisida nabati \& kimia & 50 & 100 \\
\hline & Total & 50 & 100 \\
\hline \multirow[t]{6}{*}{9.} & Alasan dilakukan pengoplosan pestisida pada waktu penyemprotan: & & \\
\hline & a. Sekaligus mencegah/mematikan beberapa jenis OPT & 18 & 36 \\
\hline & b. Hemat biaya dengan mencampur pestisida mahal \& murah & 5 & 10 \\
\hline & c. Hasil coba-coba menunjukkan efektivitas lebih tinggi dibanding pestisida tunggal & 7 & 14 \\
\hline & d. Menghemat waktu \& tenaga & 20 & 40 \\
\hline & Total & 50 & 100 \\
\hline \multirow[t]{6}{*}{10.} & Pestisida diaplikasikan terakhir kali pada saat tanaman: & & \\
\hline & a. 1-2 hari sebelum panen & 5 & 10 \\
\hline & b. 3-4 hari sebelum panen & 4 & 8 \\
\hline & c. 5-7 hari sebelum panen & 19 & 38 \\
\hline & d. Lebih dari 7 hari sebelum panen & 22 & 44 \\
\hline & Total & 50 & 100 \\
\hline \multirow[t]{6}{*}{11.} & Tindakan yang dilakukan saat mengalami kelangkaan tenaga kerja upahan: & & \\
\hline & a. Memanfaatkan TK keluarga semaksimal mungkin & 36 & 72 \\
\hline & b. Memanfaatkan TK yang ada secara bergantian & 6 & 12 \\
\hline & c. Mencari TK upahan dari luar desa / luar daerah & 8 & 16 \\
\hline & d. Memanfaatkan tenaga mekanik & 0 & 0 \\
\hline & Total & 50 & 100 \\
\hline \multirow[t]{5}{*}{12.} & Tindakan yang dilakukan jika mengalami kekurangan/kesulitan permodalan: & & \\
\hline & a. Meminjam dari sumber kredit formal: bank/pegadaian/BMT & 30 & 90 \\
\hline & b. Meminjam dari sumber kredit organisasi: keltan / gapoktan / koperasi & 19 & 4 \\
\hline & c. Meminjam dari saudara / tetangga / kerabat & 1 & 6 \\
\hline & Total & 50 & 100 \\
\hline
\end{tabular}


Petani menyatakan jika penyulaman dilakukan saat umur tanaman lebih dari satu minggu maka tanaman sulaman tidak mampu mengikuti "performance" pertumbuhan tanaman yang sudah ada. Kombinasi penggunaan mulsa dan jarak tanam dimaksudkan untuk mensiasati iklim mikro disekitar pertanaman. Petani banyak menggunakan jarak tanam rapat (74\%) karena kondisi lahan pantai yang berangin membuat lingkungan tanaman tidak lembab. Klasifikasi jarak tanam dilakukan berdasarkan masukan dari petugas penyuluh lapangan dan petani kunci.

Seluruh petani menggunakan pupuk tunggal, pupuk majemuk dan pupuk organik secara bersamaan yang diberikan sebelum pemasangan mulsa. Petani mengetahui bahwa unsur yang terdapat di dalam pupuk majemuk sama dengan yang terkandung pada pupuk tunggal, namun demikian petani masih tetap menggunakan pupuk tunggal dengan pertimbangan kandungan unsur hara makro yang lebih tinggi serta adanya kandungan hara makro lainnya yang cukup tinggi seperti sulfur pada pupuk ZA. Pupuk majemuk juga diaplikasikan sebagai pupuk susulan yaitu dengan cara dilarutkan dalam air kemudian disirimkan disekitar lubang tanam setiap dua hari satu kali. Penelitian ini mengungkap dari $62 \%$ petani yang menanam pada dua musim melakukan aplikasi pemupukan: $42 \%$ tidak berbeda jenis maupun volumenya, $45 \%$ tidak berbeda jenis namun berbeda volumenya dan $13 \%$ berbeda jenis serta volumenya. Perbedaan dosis pemupukan terjadi karena sebagian petani mengurangi volume pupuk pada musim penghujan terutama pupuk yang mengandung unsur nitrogen dengan tujuan membatasi pertumbuhan daun yang terlalu lebat, serta mencegah buah tidak lunak sehingga tidak tahan disimpan lama. Perbedaan jenis pupuk yang diaplikasikan umumnya terjadi pada aplikasi pupuk NPK, karena preferensi petani terhadap merk pupuk NPK yang beragam. Petani sudah sangat menyadari pemberian pupuk organik dapat memperbaiki sifat lahan pasir yang kurang subur sehingga mengurangi peluang terjadinya risiko produksi.

Preferensi petani melon lahan pasir terhadap aplikasi pestisida adalah sebagai berikut: $51 \%$ petani mengaplikasikan pestisida tidak berbeda jenis dan volumenya pada kedua musim, 39\% mengaplikasikan pestisida tidak berbeda jenisnya tetapi berbeda volumenya pada kedua musim dan $10 \%$ mengaplikasikan pestisida yang berbeda jenisnya dan berbeda volumenya. Kecenderungan petani untuk bertindak preventif menyebabkan penggunaan pestisida tidak berbeda jenis dan volumenya baik pada musim kemarau dan musim hujan, sesuai dengan penelitian Saptana et al., (2010) bahwa pengambilan keputusan pengendalian dengan pestisida cenderung diarahkan untuk mengantisipasi risiko terjadinya serangan OPT dan sekaligus untuk mengatasi serangan OPT tersebut. Petani (62\%) menggunakan pestisida sebagai tindakan preventif dan sekaligus kuratif, 20\% menyatakan sebagai tindakan preventif dan $18 \%$ sebagai tindakan kuratif. Ini memberikan informasi bahwa pengambilan keputusan pengendalian OPT melon lebih diarahkan untuk mengantisipasi risiko munculnya OPT dan sekaligus untuk mengatasi serangan OPT tersebut. Kondisi ini tergambar pada kondisi di lapangan, dimana 
petani selalu menyemprotkan pestisida secara periodik setiap 1-3 hari. Petani sepenuhnya mengandalkan pestisida kimiawi, sesuai dengan penelitian Zuriyah dan Happy (2013) namun berbeda dari temuan Adiyoga dan Soetiarso (1999) dan Saptana et al., (2010) dimana masih ditemukan penggunaan pestisida nabati untuk pengendalian OPT. Seluruh petani melakukan pencampuran lebih dari satu merk pestisida dalam tangki sprayer. Sebanyak $42 \%$ petani menyatakan pengoplosan ditujukan untuk menghemat waktu dan tenaga. Melon merupakan tanaman yang padat tenaga kerja dan padat modal, sehingga mencampur beberapa pestisida dalam satu kali semprot merupakan strategi petani untuk mengatasi kebutuhan tenaga kerja. Good Agriculture Practice (GAP) melon secara umum mengatur bahwa melon terakhir kali disempot saat umur 10 hari sebelum panen. Fakta dilapangan menunjukkan $10 \%$ petani menyemprotkan pestisida 1-2 hari sebelum panen, 8\% menyemprotkan 3-4 hari sebelum panen dan 38\% menjelang 5-7 hari sebelum panen. Hanya $44 \%$ petani yang telah mengikuti aturan batas akhir aplikasi pestisida dan masih ditemukan $10 \%$ petani mengaplikasikan pestisida 1-2 hari sebelum tanaman panen. Ini biasanya terjadi atas permintaan pedagang karena umumnya setelah terjadi kesapakatan antara pedagang dan petani, maka petani hanya akan melakukan pemeliharaan berupa penyiraman, tanpa penyemprotan pestisida.

Budidaya melon memerlukan tenaga kerja intensif. Mayoritas petani (72\%) memilih memanfaatkan tenaga keluarga secara maksimal jika mengalami kelangkaan tenaga kerja. Sebagian petani
(12\%) memanfaatkan tenaga kerja yang ada secara bergiliran (arisan tenaga kerja). Beberapa petani membuat kelompok untuk mengerjakan aktifitas usahataninya masingmasing secara bergantian. Alternatif mencari tenaga terja upahan dari luar desa dipilih oleh $16 \%$ petani. Budidaya melon termasuk katagori padat modal dan modal harus tersedia pada awal musim tanam. Sebanyak $90 \%$ petani mengatasi kekurangan permodalan dengan meminjam dari sumber kredit formal, mengindikasikan aksessibilitas petani terhadap lembaga kredit formal khususnya perbankan sudah baik. Ini sejalan dengan temuan dari penelitian Saptana (2010) yang menyatakan aksesibilitas petani terhadap lembaga formal/perbankan pada usahatani cabai merah sudah baik dan ketergantungan terhadap sumber kredit informal sudah berkurang, namun berbeda dengan penelitian Zuriyah \& Happy (2013) bahwa mayoritas petani bawang merah masih tergantung pada sumber kredit informal.

\section{Strategi Manajemen Risiko Ex-post}

Meskipun petani telah melaksanakan starategi manajemen risiko ex-ante dan interactive, probabilitas terjadi kegagalan panen tetap ada. Strategi untuk mengatasi setelah terjadinya goncangan berupa kegagalan panen penurunan produksi maupun penurunan penerimaan dinamakan strategi manajemen ex-post.

Tabel 5 memperlihatkan $32 \%$ petani menggantungkan sepenuhnya kehidupannya pada usahatani melon dan sebagian besar $(50 \%)$ bergantung pada usahatani melon dalam menghidupi keluarganya. Artinya usahatani melon menduduki posisi penting dalam struktur pendapatan rumah tangga 
petani. Ini berbeda dengan temuan Saptana et al., (2010) yang menyatakan bahwa petani cabai di Jawa Tengah hanya sebagian kecil menggantungkan hidupnya dari usahatani cabai. Strategi yang dipilih oleh petani (52\%) jika usahatani melon mengalami kegagalan maka untuk menutupi kebutuhan hidup keluarga dilakukan dengan mengambil pendapatan dari usahatani lainnya dan mencari pekerjaan tambahan dilakukan 28\% petani. Ini menunjukkan kemandirian petani dari segi finansial cukup baik. Apabila usahatani melon dianggap gagal, bukan berarti petani akan berhenti menanam melon pada musim selanjutnya. $72 \%$ petani akan tetap menanam melon dan mencari penyebab kegagalan.

Tabel 5. Strategi Manajemen Risiko Ex-post Petani Melon Di Lahan Pasir Pantai Kabupaten Kulon Progo

\begin{tabular}{|c|c|c|c|}
\hline No. & Uraian & Frekuensi & Persen $(\%)$ \\
\hline 1. & $\begin{array}{l}\text { Status usahatani dalam menghidupi keluarga: } \\
\text { a. Sepenuhnya bergantung pada usahatani melon } \\
\text { b. Sebagian besar bergantung pada usahatani melon } \\
\text { c. Sebagian kecil bergantung pada usahatani melon } \\
\text { Total }\end{array}$ & $\begin{array}{r}16 \\
25 \\
9 \\
50\end{array}$ & $\begin{array}{r}32 \\
50 \\
18 \\
100\end{array}$ \\
\hline 2. & $\begin{array}{l}\text { Jika usahatani melon mengalami kegagalan, upaya yang dilakukan untuk meng- } \\
\text { hidupi keluarga: } \\
\text { a. Pendapatan dari usahatani lainnya } \\
\text { b. Mengambil dari tabungan } \\
\text { c. Meminjam dari tetangga / kerabat / LKM } \\
\text { d. Mencari pekerjaan tambahan } \\
\text { e. Menjual sebagian asset yang dimiliki } \\
\text { Total }\end{array}$ & $\begin{array}{r}26 \\
2 \\
7 \\
14 \\
1 \\
50\end{array}$ & $\begin{array}{r}52 \\
4 \\
14 \\
28 \\
2 \\
100\end{array}$ \\
\hline 3. & $\begin{array}{l}\text { Jika mengalami kerugian, tindakan yang dilakukan dalam memperoleh modal } \\
\text { untuk pertanaman berikutnya: } \\
\text { a. Menyesuaikan luas pertanaman berikutnya dengan modal yang tersedia } \\
\text { b. Menambah modal dengan menggunakan tabungan } \\
\text { c. Menambah modal dengan memimjam uang pada lembaga keuangan formal } \\
\text { / non formal } \\
\text { d. Menambah modal dengan menjual asset } \\
\text { e. Mengusahakan tanaman lain yang berisiko kecil } \\
\text { Total }\end{array}$ & $\begin{array}{r}4 \\
6 \\
33\end{array}$ & $\begin{array}{r}8 \\
6 \\
100\end{array}$ \\
\hline 4. & $\begin{array}{l}\text { Tindakan yang dilakukan jika pertanaman melon gagal: } \\
\text { a. Tidak menanam pada satu atau dua musim berikutnya } \\
\text { b. Hanya menanam pada waktu musim dan waktu yang aman } \\
\text { c. Hanya akan menanam pada waktu musim dan waktu diperkirakan harga } \\
\text { baik } \\
\text { d. Tetap akan menanam dan mencari penyebab kegagalan } \\
\text { Total }\end{array}$ & $\begin{array}{l}36 \\
50\end{array}$ & $\begin{array}{r}72 \\
100\end{array}$ \\
\hline 5. & $\begin{array}{l}\text { Tindakan yang dilakukan jika pertanaman melon memberikan keuntungan: } \\
\text { a. Menyimpan sebagian keuntungan untuk antisipasi jika terjadi kegagalan } \\
\text { b. Menginvestasikan sebagian / seluruh keuntungan untuk memperbesar / } \\
\text { memperluas usahatani melon } \\
\text { c. Menginvestasikan sebagian / seluruh keuntungan untuk memperbesar / } \\
\text { memperluas usahatani selain melon } \\
\text { d. Menggunakan untuk kepentingan diluar usahatani } \\
\text { Total }\end{array}$ & $\begin{array}{l}19 \\
50\end{array}$ & $\begin{array}{r}38 \\
100\end{array}$ \\
\hline
\end{tabular}

Sumber: Analisis Data Primer, 2014.

Potensi melon sebagai komoditas tahun, meskipun mengalami kerugian. bernilai ekonomi tinggi memotivasi sebagian Kondisi ini berbeda dengan hasil penelitian besar petani menanam melon sepanjang Saptana (2010) yang memilih menyesuaikan 
luas pertanaman pada musim tanam berikutnya dengan modal yang tersedia. Petani cenderung memanfaatkan keuntungan dengan menyimpan sebagian keuntungan untuk antisipasi jika terjadi kegagalan dan untuk memenuhi kebutuhan lain, dalam kasus ini adalah untuk melunasi tunggakan kredit ataupun menebus agunan.

\section{KESIMPULAN Kesimpulan}

Petani di lahan pantai mempersepsikan melon sebagai komoditas bernilai ekonomi tinggi yang berpotensi memperbaiki pendapatan usahatani, meskipun mengandung potensi risiko usahani yang tinggi pula. Faktor eksternal dianggap petani lebih berpengaruh besar menyebabkan risiko usahatani dibanding faktor internal. Strategi manajemen risiko ex-ante pada lahan marjinal yang cenderung memiliki variasi pendapatan tinggi, pilihan budidaya secara tumpang sari atau tumpang gilir merupakan alternatif untuk membagi risiko. Rotasi lahan merupakan alternatif yang dapat dilakukan selain rotasi tanam untuk mengurangi kemungkinan terjadinya risiko usahatani. Terbuka peluang penerapan budidaya melon dengan sistem lanjaran setengah tegak (tinggi lanjaran \pm $75 \mathrm{~cm}$ ), mengingat fakta di lapangan telah dilakukan budidaya cabai yang berarti petani telah mengetahui dan mengenal teknologi ajir. Ajir digunakan untuk menggantungkan buah melon, sehingga tidak langsung bersentuhan dengan mulsa. Penguatan organisasi petani perlu ditingkatkan agar memiliki kemampuan untuk menyediakan kebutuhan modal anggotanya

Berdasar kondisi yang telah dilakukan petani melon dalam upaya melakukan manajemen risiko interactive, diketahui bahwa pemilihan musim tanam merupakan strategi penting yang dapat ditempuh. Perilaku pemupukan khususnya dalam pemberian pupuk anorganik dan aplikasi pestisida perlu diperbaiki. Secara teknis agronomis, perbedaan musim tanam akan membutuhkan dosis pemupukan dan penyemprotan pestisida yang berbeda. Arisan tenaga kerja merupakan solusi untuk mengatasi kelangkaan tenaga kerja. Usahatani melon memegang peranan penting dalam struktur pendapat rumah tangga sehingga petani cenderung untuk tetap membudidayakan meskipun mengalami kerugian dan harus menggunakan sumber modal dari luar/pinjaman. Peran organisasi petani dalam memfasilitasi kebutuhan modal bagi anggotanya masih kurang terlihat, sebaliknya aksesibilitas petani kepada lembaga keuangan formal sudah baik.

\section{Saran}

Teknologi budidaya yang diterapkan petani lahan pasir lebih banyak dilakukan berdasarkan pengalaman sendiri maupun petani lain, belum ditemukan adanya rekomendasi dari institusi atau lembaga terkait tentang teknologi budidaya melon di lahan pasir dengan sistem telasar. Dari berbagai teknologi budidaya yang telah diterapkan petani di lapangan, dapat dipilih salah satunya dan dilakukan kajian lebih lanjut untuk dijadikan rekomendasi sebagai teknologi yang tepat dan memungkinkan untuk diterapkan petani lain secara luas. Mengusahakan tanaman yang memiliki risiko lebih kecil seperti cabai merupakan langkah yang lebih tepat untuk ditempuh petani apabila mengalami kerugian dengan pertimbangan: modal yang dibutuhkan 
lebih sedikit, teknis budidaya lebih mudah dilakukan, relatif lebih tahan terhadap kondisi lingkungan pertanaman yang kurang menguntungkan, dapat dipanen beberapa kali dalam satu musim tanam serta sebagai komoditas hortikultura juga memiliki potensi keuntungan yang tinggi.

\section{DAFTAR PUSTAKA}

Adiyoga dan T. A. Soetiarso. 1999. Strategi Petani dalam Pengelolaan Risiko pada Usahatani Cabai. Jurnal Hortikultura. 8(4): 1299- 1311.

Aimin, Hao. 2010. Uncertainty, Risk Aversion and Risk Management In Agriculture. Agriculture and Agricultural Procedia I: 152156. International Conference on Agricultural Risk and Food Security. Elsevier B.V.

Borges, J.A.R. and Machado, J.A.D. 2012. Risks And Risk Management Mechanisms: An Analysis of the Perceptions of Producers Of Agricultural Commodities. Interdisciplinary Journal of Research in Business. 2(5): 27-39.

Jolly, Robert. W., 1983. Risk Management In Agricultural Production. American Journal of Agricultural Economic. 6595): 1107-1113.

Matlon, P. J. 1991 . Farmer risk management strategies : The case of the west African semi - arid tropics . In Holden, D., Hazell, P., \& Pritchard, A. (Eds). Risk in Agriculrure : Proceeding of the Tenth Agriculture Sector Symposium. The World Bank, Washington, D.C.

Martono, Arif. 2007. Kesesuaian Lahan dan Perencanaan Penggunaan Lahan untuk Pertanian di Kawasan Pesisir Kabupaten Kulon Progo, Yogyakarta. [Tesis]. Bogor:Sekolah Pasca Sarjana. Institut Pertanian Bogor.

Saptana, Daryanto, A., Daryanto, K. H., dan Kuntjoro, 2010. Strategi Management Risiko Petani Cabai Merah Pada Lahan Sawah Dataran Rendah Di Jawa Tengah. Jurnal Management Dan Agribisnis. 7(2): 115-131.

Sulewski, Piotr and Anna Kloczko Gajewska. 2014. Farmer' Risk Percepcion, Risk Aversion And Strategies To Cope Eith Production Risk: An Empirical Study From Poland. Studies In Agricultural Economics 116: 140-147. $\quad$ http://dx.doi. org/10.7896/j.1414. [14 Maret 2015]

Suratiyah, Ken. 2014. Ilmu Usahatani. Jakarta: Penebar Swadaya.

Ullah, Raza., Ganesh P. Shivakoti, Mariam Rehman and Muhammad Asif Kamran. 2015. Catastrophic Risk Management At Farm: The Use Of Diversification, Precautinary Savings And Agricultural Credit. Pakistan Journal Of Agricultural Science. 52(4): 1139-1147

Zuhriyah, Amanatuz dan Aminah Happy MA. 2013. Perilaku Petani Bawang Merah Dalam Mereduksi Risiko Sebagai Upaya Untuk Meningkatkan Produktivitas Usahatani (Studi Kasus di Kecamatan Batumarmar Kabupaten Pamekasan). Prosseding. Seminar Nasional Penerapan Ilmu Sistem dan Kompleksitas Dalam Pengembangan Agribisnis Nasional. Jatinangor 16 November 2013. 